The increased international propensity of serial entrepreneurs demonstrating ambidextrous strategic agility: a precursor to International Marketing Agility

\author{
Yancy Vaillant \\ Department of Strategy and Entrepreneurship. Toulouse Business School (TBS) \\ 1 Place Alphonse Jourdain, 31068 TOULOUSE Cedex 7, France \\ Email: y.vaillant@tbs-education.org \\ Esteban Lafuente \\ Department of Management, Universitat Politècnica de Catalunya (Barcelona Tech) \\ EPSEB, Av. Gregorio Marañón, 44-50, E-08028 Barcelona, Spain \\ Tel: +34 93405 4476, Fax: +34 933348960 \\ Email: esteban.lafuente@upc.edu
}

Paper published at the International Marketing Review. Please cite as:

Vaillant, Y, Lafuente, E. (2018). The increased international propensity of serial entrepreneurs demonstrating ambidextrous strategic agility: A precursor to international marketing agility. International Marketing Review, in press, doi: https://doi.org/10.1108/IMR-01-2018-0015 


\title{
The increased international propensity of serial entrepreneurs demonstrating
}

\author{
ambidextrous strategic agility: a precursor to International Marketing Agility
}

\begin{abstract}
:
Purpose: This paper analyzes whether business owners that simultaneously demonstrate past entrepreneurial experience and process agility have greater export propensity levels.

Design/methodology/approach: The proposed hypotheses are tested using binary choice models relating past entrepreneurial experience and reported process agility on a unique sample of 246 Catalan business owners for the year 2010.
\end{abstract}

Findings: Consistent with our theoretical arguments on the relevance of generative-based cognitive agility, results reveal that serial entrepreneurs demonstrate a greater export propensity. Additionally, we found that serial entrepreneurs who also demonstrate process agility show superior export propensity levels, compared to the group of business owners outside this ambidextrous group (first-time business owners without process agility).

Implications: The findings of this study indicate that traits characterizing international marketing agility, decisional speed and accuracy, are also linked with greater export propensity levels. The added export market expansion resulting from the opportunity responsiveness of serial entrepreneurs is found to be amplified by the accuracy of internal adaptation capabilities of process agility. Therefore, the promotion of ambidextrous strategic agility coming from the complementarities between the benefits of entrepreneurial experience and adaptive process abilities is essential for increasing businesses' internationalization.

Originality: The paper contributes to the literature by further exploring the influence of different sources of agility on the internationalization of entrepreneurial ventures and opens a link between entrepreneurs prone towards export market expansion and international marketing agility.

Keywords: Serial entrepreneurs, entrepreneurial experience, generative learning process, process agility, agility, internationalization.

JEL classification: L26, M13, M2

Article classification: Research paper 


\section{The increased international propensity of serial entrepreneurs demonstrating ambidextrous strategic agility: a precursor to International Marketing Agility}

\section{Introduction}

Observation has repeatedly been linked with opportunity identification (Vesper, 1980; Hills et al., 1999; Shane and Venkataraman, 2000). Observation may lead to the detection of trends (Barringer and Ireland, 2012), detection of problems to be solved (Baron and Ensley, 2006) or detection of gaps in the market (Trott, 2012); all aspects at the core of opportunity identification. But the recognition that an opportunity is potentially ripe for the taking (Ardichvili et al., 2003), or adequate for the specificities of an entrepreneur's business (Kirzner, 1997) requires more than just simple observation, it requires agility and talent. To be able to take on and effectively exploit an opportunity, especially when these are of a complex nature, both entrepreneurial and managerial talent are required (Corbett, 2005; Weber and Tarba, 2014). International market opportunities are very much complex ones to tackle. The parameters that command competitiveness in foreign markets often contrast from domestic ones and can be plagued with uncertainties for businesses at their first attempt at an international venture (Vendrell-Herrero et al., 2017). Finding the right balance between standardization and foreign market adaptation has been found to be a key of export performance, but such international marketing agility is not common (Vrontis et al., 2009). The key success factors required to win over foreign market demand, or to outcompete local competition often contrast with those that characterize the business strategies implemented in the home market (Gomes et al., 2011). Similarly, foreign markets are frequently framed with distinct legislative and infrastructural constraints and opportunities (Porter, 1990; Tan and Sousa, 2013).

As a result, the international marketing agility required for an optimal export market development would not seem to favor those with no prior international experience (Theodosiou and Leonidou, 2003; Poolton et al., 2006). Novice exporters tend to gain smaller export revenues (Rauch and Watson, 2003), which rarely cover the costs of international operations in 
the short-term (Das et al., 2007). Difficulties in a business' international activity not only mean potential losses of its international investment, it can often have negative effects that reverbs back on the firm's domestic activities (Amiti and Weinstein, 2011). Bellone et al. (2010) found that exporters tend to display better financial health prior, rather than after entering international markets meaning that financially-constrained firms are less likely to successfully export (Kim, 2016). These potential repercussions make international ventures more involving than most other corporate expansion decisions, and frequently dissuade business owners from venturing in international markets despite their potential strategic attractiveness (Mora, 2015).

However, not all 'wannabe’ exporters are the same, and some may bare traits and abilities that are consistent with the speed and accuracy required of international marketing agility (Junni et al., 2015b). Out of the businesses that have yet to internationalize, the ones promoted by serial entrepreneurs with past entrepreneurial experience have been found to have gained generative-based cognitive agility that may be conducive to an international orientation (Baron, 1998; Sarasvathy et al., 2013). The generative entrepreneurial learning coming from their past experience enables serial entrepreneurs to better comprehend and manage future challenges, and do so across a broader range of new situations (Huber, 1991; Cope, 2005; Keith et al., 2016). Serial entrepreneurs may therefore be better equipped to initiate international entrepreneurial activity as compared to those without such experience. Because of their past experience, serial entrepreneurs are able to identify not only better opportunities but also display greater speed and responsiveness in exploiting these opportunities (Ucbasaran et al., 2009; Bustinza et al., 2018).

But whereas entrepreneurial experience delivers a generative-based agility that is mostly explorative in nature, successful international expansion also requires the accuracy of exploitative process agility on the part of the entrepreneur (Hsu et al., 2013). The ability to conduct procedural effectiveness within current domestic operations that will allow the business to adapt and innovate in answer to the changes engendered by international expansion is also determinant of an entrepreneur's international market propensity (Chen et al., 2010). This is coherent with the fact that international orientation has been linked to more ambidextrous 
organizational structures that allow for the simultaneous tasks of exploitation and exploration (March, 1991; Luo and Rui, 2009; Prange and Verdier, 2011; Hsu et al., 2013), hence exhibiting the potential speed and accuracy that forms the basis of greater international marketing agility (Vrontis et al., 2009; Bustinza et al., 2018).

Current debates on international marketing agility indicate that businesses attempting to adopt such an internationalization strategy often face organizational tensions as a result of their lack of key capabilities (Vendrell-Herrero et al, 2017). In this study, we argue that serial entrepreneurs demonstrating process agility not only display the ambidextrous strategic agility that underlie the decisional speed and accuracy required for international marketing agility (Junni et al., 2015a; Bustinza et al., 2018), these firms are also much more prone to engage in international ventures.

Therefore, the aim of this study is to determine whether business owners that simultaneously demonstrate past entrepreneurial experience and process agility have greater export propensity levels. Does process agility increase the international market propensity of serial entrepreneurs with prior entrepreneurial experience?

The importance of this study comes from the increased promotion of international market development by entrepreneurial and SME support programs and policies (European Commission, 2014). The effectiveness of such measures is linked to the ability of selecting the appropriate beneficiaries. The complexity of international marketing agility required for export market performance (Vendrell-Herrero et al., 2017) favors a context that promotes foreign market accessibility to entrepreneurs demonstrating the decisional speed and accuracy at the basis of ambidextrous strategic agility. By identifying those business owners that are more likely to carry-through their international market expansion, internationalization promotion activities can have a more targeted and effective impact.

\section{Theoretical model and hypotheses development}

Individuals who repeat as entrepreneurs, promoting subsequent ventures, are referred to as serial entrepreneurs (Wright et al., 1997; Ucbasaran et al., 2008). Serial entrepreneurs 
represent between a third to a half of all business owners (as compiled by Uscasaran et al., 2006, p.1) and as such are relatively common (Westhead and Wright, 2015). The entrepreneurial experience of serial entrepreneurs generates learning and economic benefits which spill over from one venture into subsequent ones. As such, it has been found that individuals with past entrepreneurial experience tend to have subsequent firms that improve on the performance of their past ventures (Westhead et al., 2003; Alsos and Carter, 2006; Gompers et al., 2010; Toft-Kehler et al., 2014).

Reasons for this have been connected to how an entrepreneur's perception of new situations is in large part shaped by their entrepreneurial history. According to Cope (2005) the interaction between the past and the future that stimulates intention, entrepreneurial agility and further action lies in the generative process of entrepreneurial learning. Generative learning is described as 'the ability to extrapolate and bring forward one's learning from critical events to new situations, incidents and experiences’ (Cope, 2005, p. 386). Entrepreneurial learning is primarily experiential (Politis, 2008; Keith et al., 2016) and what an entrepreneur learns builds upon what was previously learnt to shape the 'stock' of knowledge and action that will guide future entrepreneurial behavior (Minniti and Bygrave, 2001). Generative learning is what enables serial entrepreneurs to 'abstract and generalize across contexts, to recognize patterns and build relationships between different situations and events' (Cope, 2005, p. 386).

The higher-order learning created through generative processes allows serial entrepreneurs to reach greater outcomes and levels of effectiveness, and can do so across a broader range of new situations (Cope, 2005; Keith et al., 2016). The generative entrepreneurial learning is comparable to building a greater reference frame leading serial entrepreneurs to form a cognitive schema that enables them to better comprehend and manage future entrepreneurial experiences (Huber, 1991; Cope, 2005). This generative-based cognitive agility makes serial entrepreneurs better able to understand and deal with current challenges. Individuals with past entrepreneurial experience are therefore better equipped to initiate international entrepreneurial activity as compared to those without such experience. 
Serial entrepreneurs’ cognitive schemas resulting from generative-based cognitive agility gained through entrepreneurial experience play a central role in their subsequent entrepreneurial development (Baron, 2004; Baron and Ensley, 2006). Cognitive schemas are the content and organization of knowledge resulting from cumulative experience and learning (Mitchell et al., 2004; Ucbasaran et al., 2009). Such schemas play a crucial role in pattern recognition (Krueger, 2003; Baron and Ensley, 2006). Pattern recognition is in turn an essential component of opportunity identification abilities (Gaglio, 2004; Rabetino et al., 2018). Serial entrepreneurs cultivate cognitive schemas that facilitate abstract representation and the retrieval of relevant information (Baron and Ward, 2004; Simmons et al., 2016) that are more clearly concerned with factors related to successful entrepreneurial venturing (Baron and Ensley, 2006). Baron (2004) sees that serial entrepreneurs do not face the same cognitive biases that hamper the performance of novice entrepreneurs. As opposed to inexperienced entrepreneurs, serial entrepreneurs are better able to detect meaningful patterns (Baron and Ensley, 2006). Therefore, because of this generative-based cognitive agility, serial entrepreneurs are able to identify not only more opportunities but also better opportunities (Ucbasaran et al., 2009).

Empirically, the generative-based cognitive agility coming from the entrepreneurial experience of serial entrepreneurs has been found to manifest itself in cognitive schemas that are critical for greater venturing capacity and outcomes (Van Gelderen and Jansen, 2006). Entrepreneurial experience has been shown to increase survival rates by influencing expectations and strengthening the perception of preparedness of serial entrepreneurs (Headd, 2003; Simmons et al., 2016) leading to superior performance in terms of employment (Van Praag and Cramer, 2001), economic value (Parker, 2013), and innovativeness (Ucbasaran et al., 2010; Vaillant and Lafuente, 2018).

The generative-based cognitive agility gained through entrepreneurial experience indicates that serial entrepreneurs may reach better business outcomes when measured in terms of international propensity. International opportunity recognition is related to pattern recognition which serial entrepreneurs develop from their entrepreneurial experience (Vaillant and Lafuente, 2018). Such generative-based agility explains why they may be better able to 
recognize international opportunities and are therefore more likely to internationalize as compared to novice entrepreneurs with no prior experience (Baron and Ensley, 2006). The knowledge and skills required to run an internationally oriented firm has a predominantly experiential nature (Sarasvathy et al., 2013). The persons who recognize specific opportunities are able to do so because they possess relevant generative-based cognitive agility that help them accomplish such tasks, irrespective of whether their prior entrepreneurial experience was international in nature. These frameworks enable them to perceive the emergent patterns that underlie many international opportunities (Baron and Ensley, 2006). Past entrepreneurial experience consequently influences an individual's generative-based cognitive agility in a way that is important for the decision to internationalize.

We therefore formulate the following hypothesis:

H1: Serial entrepreneurs will exhibit greater export propensity levels.

But whereas entrepreneurial experience delivers a generative-based agility that is mostly explorative in nature as it is associated with rapid decisional responsiveness and the ability to successfully confront new situations and contexts based on lessons learnt from past entrepreneurial experience, successful international expansion has been linked to more ambidextrous organizational structures that allow for the simultaneous tasks of exploitation and exploration (March, 1991; Luo and Rui, 2009; Prange and Verdier, 2011; Hsu et al., 2013). Indeed, whereas serial entrepreneurs have been found to benefit from the speed coming from generative-based cognitive agility that allow them to engage in radical and disruptive change (Vaillant and Lafuente, 2018), this speed if unaccompanied by accuracy will mostly lead to decisional errors (Weber and Tarba, 2014). This makes it particularly important for serial entrepreneurs who are perspective exporters to also be able to develop decisional accuracy coming from the monitoring and implementation process abilities that ensure risk and liability minimization (Wang and Ahmed, 2007).

Therefore, together with their gained generative-based cognitive agility, serial entrepreneurs may be advantaged in their internationalization projects by productive process 
agility. Derived from the concept of business process agility that is defined as the ease with which businesses, strategic business groups and business processes are altered to respond to external threats or opportunity (D’Aveni, 1994; Sambamurthy et al., 2003), process agility is more specifically focused on the ease of an organization to accurately adapt and bring innovative change to its productive processes (Katayama and Bennett, 2001; Alves et al., 2012).

The ambidextrous combination of generative-based cognitive and process agilities has been identified as strategic agility (Gomes et al., 2011). This ambidextrous strategic agility favors 'the selection and adoption of the right configuration at the right time' (Bustinza et al., 2018: 113), thus providing the speed and accuracy required as a pre-requisite for organizational transformation and the development of new international business models (Bauer et al., 2017; Vendrell-Herrero et al., 2018a). Such agility may facilitate the adoption of new organizational and strategic configurations in accordance to external context in a manner which allows firms to explore new markets and better generate competitive advantages (Yusuf et al., 1999).

Such agility can greatly facilitate the adaptation and response to changes provoked and/or required by operational variations (Raschke, 2010), as those brought on by international expansion. The capacity of serial entrepreneurs to swiftly and accurately reconfigure the production processes of their current ventures opens them up to greater opportunity deployment (Tallon, 2008; Tallon and Pinsonneault, 2011). Agile production processes help entrepreneurs exploit more and better opportunities for innovation and competitive actions. Building on this premise, the following hypothesis is formulated:

H2: Serial entrepreneurs who demonstrate process agility will exhibit greater export propensity levels.

\section{Data, variable definition and method}

\subsection{Data}

The model proposed in this study is tested using a unique primary dataset of the Catalan adult population that identified the activity of serial entrepreneurs. The data on entrepreneurial experience was collected for the purpose of this study and incorporated within the Catalan 
Global Entrepreneurship Monitor's (GEM) adult population survey for the year 2010. This was done in order to benefit from a rigorous and academically accepted source of randomly collected representative data offering a source of profile information on individuals and ventures. The robustness and quality of GEM's data collection process has been confirmed through the publication of several studies in leading scholarly journals (see, e.g., Lafuente et al., 2007; Vaillant and Lafuente, 2007; Driga et al., 2009; Autio and Acs, 2010; Klyver et al., 2013; Bayon et al., 2016; Lafuente et al., 2016).

The survey was conducted by a leading professional market investigation and public opinion service firm selected and monitored directly by the International GEM Consortium. The sample was built based on a multiple stage sampling method using a computer-assisted telephone interview system. First, randomly selected municipalities were chosen according to population quotas. Second, telephone numbers from these municipalities were randomly obtained from the annually updated 'España Office v5.2' database of fixed and mobile telephones. Finally, individuals aged between 18 and 65, inclusively, were randomly selected by the aforementioned software, and the data was collected between May and June 2010.

Specific questions dealing with the respondent's entrepreneurial experience were added to the structured questionnaire. This specific data allows for the study of the internationalization of serial entrepreneurs and the impact of past entrepreneurial experience on current internationalization efforts. The data also permits the analysis of the effect on the serial entrepreneur's international orientation (export propensity) of the modifications in business processes implemented within their ventures.

The final stratified random sample comprises information for 246 current business owners of which $25.6 \%$ are serial entrepreneurs with previous entrepreneurial experience.

\subsection{Variable definition}

International propensity. To evaluate the impact of serial entrepreneurs' agility on the international orientation of the entrepreneur's current venture, the dependent variable used to test the proposed hypotheses is export propensity and it is measured through a dummy variable 
taking the value of one for exporting businesses, and zero otherwise. Among the sampled entrepreneurs, $21.14 \%$ operate in foreign markets (Table 1). A more in-depth scrutiny of the data shows that the international activity of business owners with past entrepreneurial experience $(34.92 \%)$ is significantly higher $(t$-test $=3.1564, p$-value $<1 \%)$ than that reported for first-time business owners (16.39\%).

----- Insert Table 1 about here -----

Entrepreneurial experience. Entrepreneurial experience represents a key source of generative-based cognitive agility. Serial entrepreneurs with entrepreneurial experience are expected to raise their probability of international orientation in subsequent business ventures. Respondents reported whether they have owned a business in the past (yes $=1$, no $=0$ ). As we indicated above, the generative learning process of entrepreneurial experience is not task specific but rather contributes to improve the outcomes and effectiveness of serial entrepreneurs across a broader range of organizational domains. Therefore, the export activity of the current business is the result of a decision-making process in which cognitive schemas and accumulated generative-based agility resulting from past entrepreneurial experience play a key role. By definition novice entrepreneurs have no entrepreneurial experience.

Process agility. Whereas standard manufacturing agility is explorative in nature and is linked to rapid and effective response to opportunity detection (Goldman et al., 1995, Jacobs et al., 2011), process agility is more linked with the ability to internally 'retool' the productive processes to adapt to internal and external change (Chen et al., 2014). These two forms of agility complement each other and may lead to greater international propensity.

Process agility is derived from the empirically validated multi-item construct developed for the study of business process agility by Tallon (2007, 2008; Tallon and Pinsonneault, 2011). As suggested by Jacobs et al. (2011) the construct was adapted in order to capture manifested agility (over the last year), as opposed to the ability perceptions that Tallon's construct is meant to capture (Chen et al., 2014). Following Raschke (2010) efforts to adapt Tallon's construct and 
build a process-based measurement that is independent of the outcome metrics, the final process agility construct used in this study is limited in focus to new process technology adoption and productive process adaptability. This is the result of the elimination from Tallon's construct of items related to international market expansion and marketing strategies, which coincide with our dependent variable as well as those linked to external processes (Tallon, 2008). The result is a perception-based agility measure of new process technology adoption and productive process adaptability during the year leading up to the survey.

Control variables. We control for gender, entrepreneur’s age, education attainment, business size, business age, perceived competitive intensity and industry in our model specification. Gender identifies whether the individual is a male (yes=1, no=0), whereas age is expressed in years. The individual's education attainment is captured through a set of dichotomous variables distinguishing individuals with primary studies (yes $=1$, no $=0$ ), secondary studies (yes $=1, \mathrm{no}=0$ ), and post-secondary studies (yes $=1, \mathrm{no}=0$ ). These variables have been used in prior studies on entrepreneurial activity (see, e.g., Lafuente et al., 2007; Driga et al., 2009; Autio and Acs, 2010; Bosma et al., 2012).

Concerning the control variables related to the business, size is measured by the number of employees, while business age is expressed in years since the current business started its operations. These two variables measure the vulnerability of the firm to market conditions due to liabilities of smallness and newness (Wiklund et al., 2010; Ucbasaran et al., 2013). The business' competitive environment can play a key role in explaining the decision to engage in international activities. We include two sets of variables to capture the business' competitive environment. Entrepreneurs were asked to provide information about the number of competitors that the business has according to the following categories: 'none', 'few' and 'many'. These dummy variables are not significantly correlated to export propensity. Thus, a single dichotomous variable was introduced indicating if the business has many competitors or not (yes $=1$, no=0). Respondents also indicated the business' primary activity with regard to the following categories: extractive sectors, manufacturing, business services, and consumer 
services. Based on these data a set of industry dummy variables were created. Finally, the variables entrepreneur's age, business size and business age were logged to reduce skewness.

It should be noted that in coherence with recent studies that highlight that productivity tends to be uncorrelated to exports in entrepreneurial ventures (Gomes et al., 2018), we have not included controls for productivity into our model. In-fact, the potential for self-selection problems that are sometimes raised within the export literature (Melitz, 2003) does not apply in the specific context in which this study is conducted.

\subsection{Method}

To correctly test the proposed hypotheses that emphasize the role of past entrepreneurial experience and process agility on the export propensity of entrepreneurial ventures, we have chosen the binary choice (logit) regression model as a methodological tool (Greene, 2003). The logit model is estimated by maximum likelihood method, and the full model used to test our hypotheses has the following form:

$$
\begin{aligned}
& \text { Export } \\
& \begin{aligned}
\text { propensity }_{i} & =\beta_{0} \text { Constant }_{i}+\beta_{1} \text { Past entrepreneurial experience }_{i}+\beta_{2} \text { Process agility }_{i} \\
& +\beta_{12} \text { Past entrepreneurial experience }_{i} \times \text { Process agility }_{i} \\
& +\beta_{3} \text { Control variables }_{i}+\varepsilon_{i}
\end{aligned}
\end{aligned}
$$

In equation (1) $\beta_{0}$ is the constant term, $\beta_{j}$ refers to the vector of parameter estimates computed for the $j$ th independent variables, and $\varepsilon_{i}$ is the logistic distributed error term estimated for each observation in the sample (i). The control variables correspond to the entrepreneur's profile (gender, age, educational attainment) and to the business profile (business size, business age, perceived competitive intensity, and sector dummies).

Note that coefficients estimated by discrete choice models only indicate the direction of the effect of the analyzed variable on the response probability. For interpretation purposes, the magnitude of the key independent variables is determined by the average marginal effect (AME). The marginal effect is the slope of the probability curve relating a focal variable $(x)$ to 
$\operatorname{Pr}(y=1 \mid x)$ holding all other variables constant, and the AME is the average change in the probability of the response variable as a result of a change in an independent variable across the sampled observations. The AMEs is particularly informative because it calculates marginal effects at every observed value of $x$ and average across the resulting effect estimates. Through this approach we can estimate marginal effects for each observation, thus the resulting AME not only captures individual-specific characteristics, but also gives more realistic estimation results (Greene, 2003). For each independent variable (x) the AME is estimated as $A M E_{\mathbf{x}}=\frac{1}{N} \sum_{i=1}^{N}\left\{F\left(\beta \mathbf{x} \mid \mathbf{x}_{i}=1\right)-F\left(\beta \mathbf{x} \mid \mathbf{x}_{i}=0\right)\right\}$ (Cameron and Trivedi, 2010).

The average marginal effects apply in the case of individual independent variables since unlike linear models, in non-linear models the interaction effect of a change in both interacted variables does not equal to that AME of changing just the interaction term. In addition, in the case of the interaction of two dummy variables in non-linear models, the interaction effect may have different signs for different values of covariates. Therefore, in this case the parameter estimate of the interaction term does not necessarily indicate the sign of the interaction effect.

Because in this paper we focus on the influence of past entrepreneurial experience and process agility upon the export propensity of entrepreneurial ventures, the analysis of the direct AME of the interaction term will provide misleading results. Therefore, to corroborate our theoretical framework, and to accurately identify the effect of both traits-i.e., past entrepreneurial experience and process agility—on the probability to engage in international activities—in terms of export propensity—we make use of the methodological approach proposed by Ai and Norton (2003). Through this procedure we obtain robust interaction effects for the variables of interest, where for the case of two dummy variables $\left(x_{1}, x_{2}\right)$, the average change in the predicted probability of exporting results from the discrete double difference with respect to $x_{1}$ and $x_{2}$, i.e., $\hat{\gamma}_{x_{1}, x_{2}}=\frac{\Delta^{2} F(X, \hat{\beta})}{\Delta x_{1} \Delta x_{2}}$, where $X=x_{1}, x_{2}$. Prior studies dealing with entrepreneurship (Driga et al., 2009) and internationalization (Vendrell-Herrero et al., 2018b) 
have adopted this methodological approach to analyze the effect of multiplicative variables in binary choice models.

In terms of the study hypotheses, we expect that the AME of the coefficient linked to past entrepreneurial experience to be positive, meaning that past entrepreneurial experience positively impacts the probability to engage in international activities (i.e., export propensity) (H1). Additionally, we expect that $\hat{\gamma}_{x_{1}, x_{2}}>0$ to corroborate that the probability to engage in international activities (i.e., export propensity) is greater in serial entrepreneurs who demonstrate process agility (H2).

\section{Results}

From a purely descriptive perspective it can be seen in Figure 1 that the group of business owners with both agility measures analyzed in this study demonstrate the highest export propensity level (53.33\%). To the contrary, the group characterized by neither of these agility variables is found to have the lowest export propensity level (15.29\%) of all the sampled business owners.

----- Insert Figure 1 about here -----

The results of our logit model are summarized in Table 2 below. This model tests the impact of the variables linked to the different sources of agility and control variables over the international market propensity of the sampled business owners. Results presented in the table include, for each variable, parameter estimates and the average marginal effect (AME).

To address the threat of collinearity, we computed the variance inflation factor (VIF) for all variables and summary results are presented in Table 2. In our model specification, the average VIFs do not exceed 10—a generally accepted rule of thumb for assessing collinearity— and ranges between 1.04 and 2.47. The result of this diagnostic test does not raise collinearity concerns. Also, Table A1 in the Appendix shows that the bivariate correlations among the study variables are generally in the low to moderate range. 
Starting with the selected control variables, we can see in Table 2 that with the exception of educational attainment and business size the individual and business profile variables are not significantly influencing the international market propensity of the sampled business owners. When the influence of the educational attainment of the business owner over their international propensity is considered, we find that business owners with lower educational attainment levels (with maximum formal educational attainment at a primary level or lower) are found to have significantly less international propensity levels when compared to business owners with post-secondary education. This finding is consistent with that of Hsu et al. (2013) who find that entrepreneurs with greater levels of scholar attainment tend to demonstrate higher export propensity levels. In the case of the variable linked to business size, and similar to the findings reported by Bernard and Jensen (2004) and Das et al. (2007), we found that larger businesses have a greater probability to engage in international activities. This result may indicate that larger organizations have a greater capacity to cover the initial investments and sunk costs associated with exporting activities.

\section{----- Insert Table 2 about here -----}

As for the study's main independent variables guiding the set hypotheses, the results of the logit model (Table 2) indicate that business owners with past entrepreneurial experience are found to be significantly more likely to engage in international activities-i.e., export propensity—as compared to novice business owners who are promoting their first venture. The greater export propensity demonstrated by serial entrepreneurs is coherent with the development of generative-based cognitive agility as a result of past entrepreneurial experience upon which our theoretical argument is based. This finding gives support to the study's hypothesis H1, which states that serial entrepreneurs exhibit greater export propensity levels. Looking at the results of the average marginal effect in Table 2, we can see that the probability of exporting increases 11.60 percentage points among business owners with past entrepreneurial experience, relative to the probability of first-time business owners. 
When analyzing the result corresponding to the effect of process agility on export propensity on its own, we find that such relationship does not present a level of significance that is sufficient for us to make any interpretation. However, the interaction term between the variable capturing serial entrepreneurs and the variable linked to process agility does provide a positive and statistically significant result when related to export propensity levels. For illustrative purposes, Figure 2 displays the empirically constructed effect over export propensity of the interaction term between past entrepreneurial experience and process agility. To ease readability, Figure 2 distinguishes the effect on export propensity of process agility among firsttime novice business owners (left-hand side) from the effect of having past entrepreneurial experience among individuals with and without process agility (right-hand side). Additionally, Figures 3 and 4 plot the correct interaction term between past entrepreneurial experience and process agility and its significance, respectively.

----- Insert Figures 2, 3 and 4 about here -----

From Table 2 we know that the estimated coefficient for process agility is not significant, and the results in Figure 2 indicate that the positive relationship between process agility and export propensity is steeper for the group of business owners with past entrepreneurial experience. That is, the effect of process agility turns out statistically significant only among business owners with prior entrepreneurial experience. The results in Table 2 and Figure 2 indicate that as compared to those first-time business owners without process agility, business owners with the ambidextrous strategic agility manifested through their past entrepreneurial experience and process agility are found to have greatest export propensity levels. This finding is further validated by the results presented in Figures 3 and 4. For firms whose estimated probability of exporting is below $15 \%$ the interaction term between past entrepreneurial experience and process agility is mostly not significant, while the interaction effect for firms with an estimated probability of exporting above $15 \%$ is statistically significant. 
These results therefore gives support to the study's second hypothesis H2, which states that serial entrepreneurs who demonstrate process agility will exhibit greater export propensity levels. From the result of the robust marginal effect found in Table 2, we can see that the international propensity of the group of business owners who simultaneously demonstrate both analyzed agility indicators is 23.31 percentage points greater than that of business owners outside this ambidextrous group (first-time business owners without process agility).

\section{Discussion, implications and concluding remarks}

With this study, the aim was to determine whether business owners that simultaneously demonstrate past entrepreneurial experience and process agility reported greater export propensity levels. Strong theoretical arguments based on the generative process of experiential entrepreneurial learning would lead to indicate that business owners who have had prior entrepreneurial experience would be more likely to exploit export market opportunities as a result of the gained generative-based cognitive agility (Huber, 1991; Cope, 2005). But by adding to this the posits from strategic agility (Weber and Tarba, 2014) and ambidexterity (March, 1991; Junni et al., 2015a), that have already been linked to international marketing agility and success (Luo and Rui, 2009; Hsu et al., 2013), it was hypothesized that serial entrepreneurs with past entrepreneurial experience who also manifested process agility with their current business — contributors of decisional speed and accuracy that are components of what was referred to in this study as ambidextrous strategic agility—would be most likely to demonstrate export propensity.

To test this postulate, a binary choice (logit) regression model estimated by maximum likelihood method was performed using a unique primary dataset of 246 Catalan business owners for the year 2010. The magnitude of the key independent variables was determined by its average marginal effect (AME). By calculating robust change in the probability of the response variable as a result of a change in the modeled independent variables across the sampled observations, the study is able to answer its research question and conclude that 
process agility does increase the international market propensity of serial entrepreneurs with prior entrepreneurial experience.

Because being internationally active is found to be strongly related to higher turnover growth, relatively higher employment growth, and stronger innovation; internationalization can result in competitiveness gains at firm level which may eventually translate into improved economic performance at national level (European Commission, 2014). The promotion of international market development by specific support programs and policies therefore becomes highly justified. The effectiveness of such measures is however linked to the ability of selecting the appropriate beneficiaries (ECSIP Consortium, 2013). Not only is the decisional speed and accuracy at the foundations of ambidextrous strategic agility found in our study to jointly be key contributors to international sales activities, but these abilities are also associated with the international marketing agility required for greater export market performance (Junni et al., 2015a; Vendrell-Herrero et al., 2017). This favors a context that promotes foreign market accessibility to entrepreneurs demonstrating signs of ambidextrous strategic agility. By finding that business owners demonstrating ambidextrous strategic agility are most likely to carrythrough their international market expansion, the results of this study imply that internationalization promotion activities can have a more targeted and effective impact.

Much attention has been placed on the exploratory and entrepreneurial nature of international opportunity identification. But the findings of this study indicate that the export market expansion resulting from opportunity exploitation is amplified by the decisional accuracy from internal adaptation capabilities described as process agility (Wang and Ahmed, 2007). Business owners are more prone to internationalize if they complement their rapid entrepreneurial responsiveness with the decisional accuracy of operational and adaptive abilities.

Further research is needed to push the analysis of the importance of ambidextrous strategic agility for international business. Beyond export propensity, the combination of generative-based cognitive agility coming from past entrepreneurial experience and productive process agility may positively influence the international trajectory, intensity and performance 
of serial entrepreneurs. Their needs to be further research into the exact mechanics that link ambidextrous strategic agility with the performance enhancing capabilities of firms demonstrating international marketing agility. Likewise, a more complex and detailed process agility construct may offer greater specifications of the effective internal agility requirements for successful internationalization. Finally, the specific geographic context and cross-sectional analysis used in this study affect the ability to generalize and carry over its findings to other unexplored contexts and periods.

\section{References}

Ai, Ch. and Norton, E. (2003), "Interaction terms in logit and probit models”, Economics Letters, Vol. 80, pp. 123-129.

Alsos, G.A. and Carter, S. (2006), "Multiple business ownership in the Norwegian farm sector: Resource transfer and performance consequences”, Journal of Rural Studies, Vol. 22, pp. 313-322.

Alves, A., Dinis-Carvalho, J. and Sousa, R.M. (2012), "Lean production as promoter of thinkers to achieve companies’ agility”, The Learning Organization, Vol. 19 No. 3, pp. 219-237.

Amiti, M. and Weinstein, D. (2011), “Exports and Financial Shocks”, Quarterly Journal of Economics, Vol. 126 No. 4, pp. 1841-1877.

Ardichvili, A., Cardozo, R. and Ray, S. (2003), “A theory of entrepreneurial opportunity identification and development”, Journal of Business Venturing, Vol. 18, pp. 105-123.

Autio, E. and Acs, Z. (2010), "Intellectual property protection and the formation of entrepreneurial growth aspirations”, Strategic Entrepreneurship Journal, Vol. 4 No. 3, pp. 234-251.

Baron, R. (1998), “Cognitive mechanisms in entrepreneurship: why and when entrepreneurs think differently than other people”, Journal of Business Venturing, Vol. 13, pp. 275-294.

Baron, R. (2004), “The cognitive perspective: a valuable tool for answering entrepreneurship’s basic “why” questions”, Journal of Business Venturing, Vol. 19, pp. 221-239. 
Baron, R. and Ensley, M. (2006), “Opportunity Recognition as the Detection of Meaningful Patterns: Evidence from Comparisons of Novice and Experienced Entrepreneurs”, Management Science, Vol. 52 No. 9, pp. 1331-1344.

Baron, R. and Ward, T. (2004), “Expanding Entrepreneurial Cognition’s Toolbox: Potential Contributions from the Field of Cognitive Science”, Entrepreneurship Theory \& Practice, Vol. 28, pp. 553-573.

Barringer, B. and Ireland, R. (2012), Entrepreneurship: Successfully Launching New Ventures (4th Global Edition), Pearson Higher Education, London (UK).

Bauer, F., Dao, M. A., Matzler, K., Tarba, S. Y. (2017), “How Industry Lifecycle Sets Boundary Conditions for M\&A Integration”, Long Range Planning, Vol. 50 No. 4, pp. 501-517.

Bayon, M, Lafuente, E. and Vaillant, Y. (2016), “Human capital and the decision to exploit innovative opportunity”, Management Decision, Vol. 54 No. 7, pp. 1615-1632.

Bellone, F., Musso, P., Nesta, L., Schiavo, S. (2010), “Financial Constraints and Firm Export Behaviour”, The World Economy, Vol. 33 No. 3, pp. 347-373.

Bernard, A.B. and Jensen, J.B. (2004), "Why some firms export”, Review of Economics and Statistics, Vol. 86 No. 2, pp. 561-569.

Bosma, N., Hessels, J., Schutjens, V., Van Praag, M. and Verheul, I. (2012), “Entrepreneurship and role models”, Journal of Economic Psychology, Vol. 33 No. 2, pp. 410-424.

Bustinza, O.F., Gomes, E., Vendrell-Herrero, F., Tarba, S. (2018), “An organisational change framework for digital servitization: Evidence from the Veneto region”, Strategic Change, in press.

Cameron, A.C. and Trivedi, P.K. (2010), Microeconometrics Using Stata, Stata Press, College Station, TX.

Corbett, A. (2005), “Experiential Learning within the Process of Opportunity Identification and Exploitation”, Entrepreneurship Theory \& Practice, Vol. 29 No. 4, pp. 473-491. 
Chen, E.L., Katila, R., McDonald, R. and Eisenhardt, K.M. (2010), “Life in the fast lane: origins of competitive interaction in new vs. established markets”, Strategic Management Journal, Vol. 31 No. 13, pp. 1527-1547.

Chen, Y., Wang, Y., Nevo, S., Jin, J., Wang, L. and Chow, W. (2014), “IT capability and organizational performance: the roles of business process agility and environmental factors”, European Journal of Information Systems, Vol. 23 No. 3, pp. 326-342.

Cope, J. (2005), “Towards a dynamic learning perspective of entrepreneurship”, Entrepreneurship Theory \& Practice, Vol. 29 No. 4, 373-397.

Das, S., Roberts, M.J. and Tybout, J.R. (2007), “Market entry costs, producer heterogeneity, and export dynamics”, Econometrica, Vol. 75, pp. 837-873.

D’Aveni, R.A. (1994), Hypercompetition: Managing the Dynamics of Strategic Maneuvering, Free Press, New York.

Driga, O., Lafuente, E. and Vaillant, Y. (2009), “Reasons behind the relatively lower entrepreneurial activity levels of rural women: Looking into rural Spain”, Sociologia Ruralis, Vol. 49 No. 1, pp. 70-96.

ECSIP Consortium (2013), Study on Support Services for SMEs in International Business. Final Report: Within the Framework Contract for Industrial Competitiveness and Market Performance - ENTR/90/PP/2011/FC DG Enterprise and Industry, European Commission. Rotterdam, Netherlands.

European Commission (2014), Supporting the Internationalisation of SMEs. Guidebook Series: How to support SME Policy from Structural Funds. Office for Official Publications of the European Union: Luxembourg.

Gaglio, C.M. (2004), “The role of mental simulations and counterfactual thinking in the opportunity identification process”, Entrepreneurship Theory \& Practice, Vol. 28 No. 6, pp. 533-552.

Goldman, S. L., Nagel, R. N. and Preiss, K. (1995), Agile competitors and virtual organizations: strategies for enriching the customer, Van Nostrand Reinhold, New York. 
Gomes, E., Weber, Y., Brown, C. and Tarba, S.Y. (2011), Mergers, Acquisitions and Strategic Alliances: Understanding the Process, Palgrave Macmillan, Basingstoke, UK.

Gomes, E., Vendrell-Herrero, F., Mellahi, K., Angwin, D., \& Sousa, C. M. (2018), “Testing the self-selection theory in high corruption environments: evidence from exporting African SMEs”, International marketing review. In press.

Gompers, P., Kovner, A., Lerner, J. and Scharfsteina, D. (2010), “Performance persistence in entrepreneurship”, Journal of Financial Economics, Vol. 96, pp. 18-32.

Greene, W. (2003), Econometric Analysis (5th edition), Prentice Hall, Upper Saddler River, NJ.

Headd, B. (2003), “Redefining business success: Distinguishing between closure and failure”, Small Business Economics, Vol. 21, pp. 51-62.

Hills, G.E., Shrader, R.C. and Lumpkin, G.T. (1999), “Opportunity recognition as a creative process”, Frontiers of Entrepreneurship Research, pp. 216-227.

Hsu, W.T, Chen, H. and Cheng, C.Y. (2013), "Internationalization and firm performance of SMEs: The moderating effects of CEO attributes”, Journal of World Business, Vol. 48 No. 1, pp. 1-12.

Hsu, C.W., Lien, Y.C. and Chen, H. (2013), "International ambidexterity and firm performance in small emerging economies”, Journal of World Business, Vol. 48 No. 1, pp. 58-67.

Huber, G. (1991), “Organizational Learning: The contributing process and the literatures”, Organization Science, Vol. 2 No. 1, pp. 88-115.

Jacobs, M., Droge, C., Vickery, S.K. and Calantone, R. (2011), “Product and Process Modularity's Effects on Manufacturing Agility and Firm Growth Performance”, Journal of Product Innovation Management, Vol. 28 No. 1, pp. 123-137.

Junni, P., Sarala, R.M., Tarba, S.Y., Liu, Y., \& Cooper, C. (2015a). The Role of Human Resource and Organizational Factors in Ambidexterity: A State-of-Art Review, Human Resource Management, 54 (S1), s1-s28.

Junni, P., Sarala, R.M., Tarba, S.Y. and Weber, Y. (2015b), "The role of strategic agility in acquisitions”, British Journal of Management, Vol. 26 No. 4, pp. 596-616. 
Katayama, H. and Bennett, D. (2001), “Agility, adaptability and leanness: A comparison of concepts and a study of practice”, in Gunasekaran, A. (Ed.), Agile Manufacturing: The 21st Century Competitive Strategy, Elsevier Science, Amsterdam, The Netherlands, pp.483-498.

Keith, N., Unger, J. M., Rauch, A. and Frese, M. (2016), “Informal Learning and Entrepreneurial Success: A Longitudinal Study of Deliberate Practice among Small Business Owners”, Applied Psychology, Vol. 65, pp. 515-540.

Kim, H.S. (2016), “Firms’ leverage and export market participation: Evidence from South Korea”, International Economics, Vol. 148, pp. 41-58.

Kirzner, I.M. (1997), “Entrepreneurial Discovery and the Competitive Market Process: An Austrian Approach”, Journal of Economic Literature, Vol. 35 No. 1, pp. 60-85.

Klyver, K., Nielsen, S.L. and Evald, M.R. (2013), “Women’s self-employment: An act of institutional (dis)integration? A multilevel, cross-country study”, Journal of Business Venturing, Vol. 28 No. 4, pp. 474-488.

Krueger, N. (2003), “The Cognitive Psychology of Entrepreneurship”, International Handbook Series on Entrepreneurship, Vol. 1, pp. 105-140.

Lafuente, E., Szerb, L. and Acs, Z.J. (2016), “Country level efficiency and national systems of entrepreneurship: a data envelopment analysis approach”, Journal of Technology Transfer, Vol. 41 No. 6, pp. 1260-1283.

Lafuente, E., Vaillant, Y. and Rialp J. (2007), “Regional differences in the influence of RoleModels: Comparing the Entrepreneurial Process of Rural Catalonia”, Regional Studies, Vol. 41 No. 6, pp. 779-796.

Luo, Y. and Rui, H. (2009), “An Ambidexterity Perspective Toward Multinational Enterprises From Emerging Economies”, Academy of Management Perspectives, Vol. 23, pp. 49-70. March, J.G. (1991), “Exploration and exploitation in organizational learning”, Organization Science, Vol. 2 No. 1, pp. 71-87.

Melitz, M.J. (2003), “The Impact of Trade on Intra-Industry Reallocations and Aggregate Industry Productivity”, Econometrica, Vol. 71 No. 6, pp. 1695-1725. 
Minniti, M. and Bygrave, W. (2001), “A dynamic model of entrepreneurial learning”, Entrepreneurship Theory \& Practice, Vol. 25 No. 3, pp. 5-16.

Mitchell, R.K., Busenitz, L., Lant, T., McDougall, P.P., Morse, E.A. and Smith, J.B. (2004), “The Distinctive and Inclusive Domain of Entrepreneurial Cognition Research”, Entrepreneurship Theory \& Practice, Vol. 28 No. 6, pp. 505-518.

Mora, J. (2015), “Export Failure and Its Consequences: Evidence from Colombian Exporters”, in Working Paper series, Department of Economics, Occidental College (California, USA).

Parker, S.C. (2013), “Do serial entrepreneurs run successively better-performing businesses?”, Journal of Business Venturing, Vol. 28 No. 5, pp. 652-666.

Politis, D. (2008), “Does prior start-up experience matter for entrepreneur's learning? A comparison between novice and habitual entrepreneurs”, Journal of Small Business and Enterprise Development, Vol. 15 No. 3, pp. 472-489.

Poolton, J., Ismail, H.S., Reid, I.R. and Arokiam, I.C. (2006), “Agile marketing for the manufacturing-based SME”, Marketing Intelligence \& Planning, Vol. 24 No. 7, pp. 681693.

Porter, M.E. (1990), The Competitive Advantage of Nations, Free Press, New York.

Prange, C. and Verdier, S. (2011), "Dynamic capabilities, internationalization process and performance”, Journal of World Business, Vol. 46, pp. 126-133.

Rabetino, R., Johnson Ogundipe, S. and Kohtamäki, M. (2018), “Solution sales process blueprinting”, International Journal of Business Environment, in press.

Raschke, R. (2010), “Process-based view of agility: The value contribution of IT and the effects on process outcomes”, International Journal of Accounting Information Systems, Vol. 11 No. 4, pp. 297-313.

Rauch, J. and Watson, J. (2003), “Starting small in an unfamiliar environment”, International Journal of Industrial Organization, Vol. 21 No. 7, pp. 1021-1042.

Sambamurthy, V., Bharadwaj, A. and Grover, V. (2003), "Shaping Agility through Digital Options: Reconceptualizing the Role of Information Technology in Contemporary Firms”, MIS Quarterly, Vol. 27 No. 2, pp. 237-263. 
Sarasvathy, S., Menon, A. and Kuechle, G. (2013), "Failing firms and successful entrepreneurs: serial entrepreneurship as a temporal portfolio”, Small Business Economics, Vol. 40, pp. 417-434.

Shane, S. and Venkataraman, S. (2000), “The promise of entrepreneurship as a field of research”, Academy of Management Review, Vol. 25 No. 1, pp. 217-226.

Simmons, S.A., Carr, J.C., Hsu, D.K. and Shu, C. (2016), “The regulatory fit of serial entrepreneurship intentions”, Applied Psychology: An International Review, Vol. 65 No. 3, pp.603-627.

Tallon P.P. (2007), “Does IT pay to focus? An analysis of IT business value under single and multi-focused business strategies”, Journal of Strategic Information Systems, Vol. 16 No. 3, pp. 278-300.

Tallon P.P. (2008), “A process-oriented perspective on the alignment of information technology and business strategy”, Journal of Strategic Information Systems, Vol. 24, pp. 227-268.

Tallon P.P. and Pinsonneault A. (2011), “Competing perspectives on the link between strategic information technology alignment and organizational agility: Insights from a mediation model”, MIS Quarterly, Vol. 35 No. 2, pp. 463-484.

Tan, Q. and Sousa, C.M. (2013), "International marketing standardization: a meta-analytic estimation of its antecedents and consequences”, Management International Review, Vol. 53 No. 5, pp. 711-739.

Theodosiou, M. and Leonidou, L.C. (2003), "Standardization versus adaptation of international marketing strategy: an integrative assessment of the empirical research”, International Business Review, Vol. 12 No. 2, pp. 141-171.

Toft-Kehler, R., Wennberg, K. and Kim P. (2014), “Practice makes perfect: Entrepreneurialexperience curves and venture performance”, Journal of Business Venturing, Vol. 29 No. 4, pp. 453-470.

Trott, P. (2012), Innovation management and new product development (5th edition), Prentice Hall, London, UK. 
Ucbasaran, D., Alsos, G.A., Westhead, P. and Wright, M. (2008), “Habitual Entrepreneurs”, Foundations and Trends in Entrepreneurship, Vol. 4 No. 4, pp. 309-450.

Ucbasaran, D., Shepherd, D.A., Lockett, A. and Lyon, S.J. (2013), “Life after Business Failure: The Process and Consequences of Business Failure for Entrepreneurs”, Journal of Management, Vol. 39 No. 1, pp. 163-202.

Ucbasaran, D., Westhead, P. and Wright, M. (2006), Habitual Entrepreneurs, Edward Elgar Publishing, Aldershot, UK.

Ucbasaran, D., Westhead, P. and Wright, M. (2009), “The extent and nature of opportunity identification by experienced entrepreneurs”, Journal of Business Venturing, Vol. 24 No. 2, pp. 99-115.

Ucbasaran, D., Westhead, P., Wright, M. and Flores, M. (2010), “The nature of entrepreneurial experience, business failure, and comparative optimism”, Journal of Business Venturing, Vol. 25 No. 6, pp. 541-555.

Vaillant, Y. and Lafuente, E. (2018), "Entrepreneurial Experience and the Innovativeness of Serial Entrepreneurs”, Management Decision, in press.

Vaillant, Y. and Lafuente, E. (2007), “Do Different Institutional Frameworks Condition the Influence of Local Fear of Failure and Entrepreneurial Examples over Entrepreneurial Activity?”, Entrepreneurship and Regional Development, Vol. 19 No. 4, pp. 313-337. Van Gelderen, M.W. and Jansen, P.G.W. (2006), “Autonomy as a startup motive”, Journal of Small Business and Enterprise Development, Vol. 13 No. 1, pp. 23-32.

Van Praag, C.M. and Cramer, J.S. (2001), “The Roots of Entrepreneurship and Labour Demand: Individual Ability and Low Risk Aversion”, Economica, Vol. 68 No. 269, pp. 45-62.

Vendrell-Herrero, F., Gomes, E., Mellahi, K. and Child, J. (2017), “Building international business bridges in geographically isolated areas: The role of foreign market focus and outward looking competences in Latin American SMEs”, Journal of World Business, Vol. 52, pp. 489-502. 
Vendrell-Herrero, F., Gomes, E., Collinson, S., Parry, G. and Bustinza, O. F. (2018a), “Selling digital services abroad: How do extrinsic attributes influence foreign consumers' purchase intentions?”, International Business Review, 27(1), 173-185.

Vendrell-Herrero, F., Parry, G. and Opazo, M. and Sanchez-Montesinos, F.J., (2018b), “Does business model experimentation in dynamic contexts enhance value capture?”, International Journal of Business Environment, in press.

Vesper, K. (1980), New venture strategies, Prentice-Hall, New York.

Vrontis, D., Thrassou, A. and Lamprianou, I. (2009), “International marketing adaptation versus standardisation of multinational companies”, International Marketing Review, Vol. 26 No. 4, pp. 477-500.

Wang, C.L. and Ahmed, P.K. (2007), “Dynamic capabilities: A review and research agenda”, International Journal of Management Reviews, Vol. 9, pp. 31-51.

Weber, Y. and Tarba, S.Y. (2014), “Strategic agility: a state of the art”, California Management Review, Vol. 56 No. 3, pp. 5-12.

Westhead, P., Ucbasaran, D. and Wright, M. (2003), “Differences between private firms owned by novice, serial and portfolio entrepreneurs: implications for policy-makers and practitioners”, Regional Studies, Vol. 37, pp. 187-200.

Westhead, P. and Wright, M. (2015), “The habitual entrepreneur phenomenon”, International Small Business Journal, Virtual Special Issue, pp. 1-16.

Wiklund, J., Baker, T. and Shepherd, D. (2010), “The age-effect of financial indicators as buffers against the liabilities of newness”, Journal of Business Venturing, Vol. 25 No. 4, pp. 423-437.

Wright, M., Robbie, K. and Ennew, C. (1997), "Venture capitalists and serial entrepreneurs”, Journal of Business Venturing, Vol. 12 No. 3, pp. 227-249.

Yusuf, Y. Y., Sarhadi, M., Gunasekaran, A. (1999), “Agile manufacturing: The drivers, concepts and attributes”, International Journal of production economics, Vol. 62 No. 1-2, pp. 33-43. 


\section{List of Figures}

Figure 1. Proportion of business owners in each agility category

\begin{tabular}{|c|c|c|}
\hline \multicolumn{3}{|c|}{$\begin{array}{l}\text { Entrepreneurial } \\
\text { experience }\end{array}$} \\
\hline Yes & $29.17 \%$ & $53.33 \%$ \\
\hline \multirow[t]{2}{*}{ No } & $15.29 \%$ & $30.77 \%$ \\
\hline & No & Yes \\
\hline
\end{tabular}

Figure 2. The effect of the analyzed sources of agility on the predicted probability to export

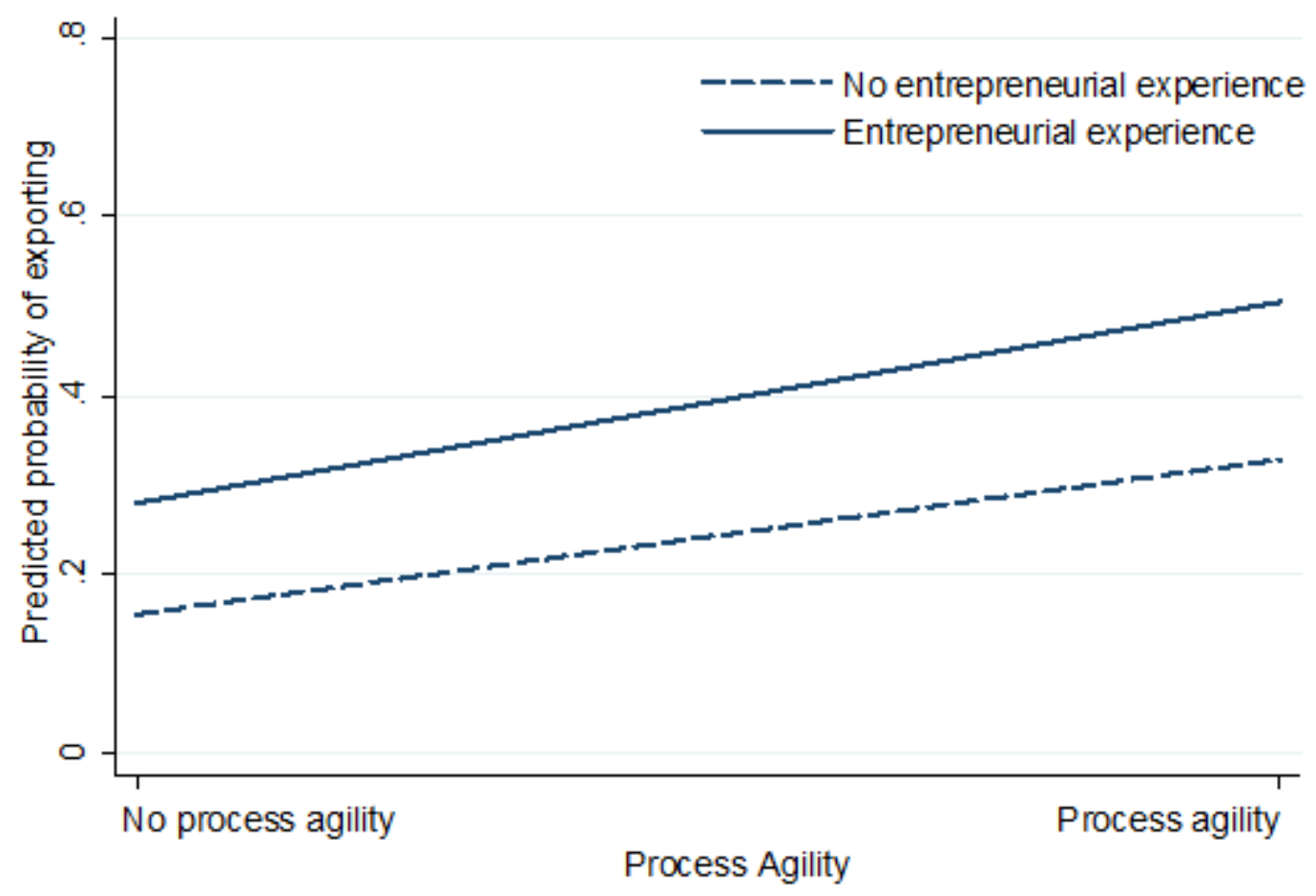


Figure 3. The probability to export as a function of the interaction term between the analyzed sources of agility

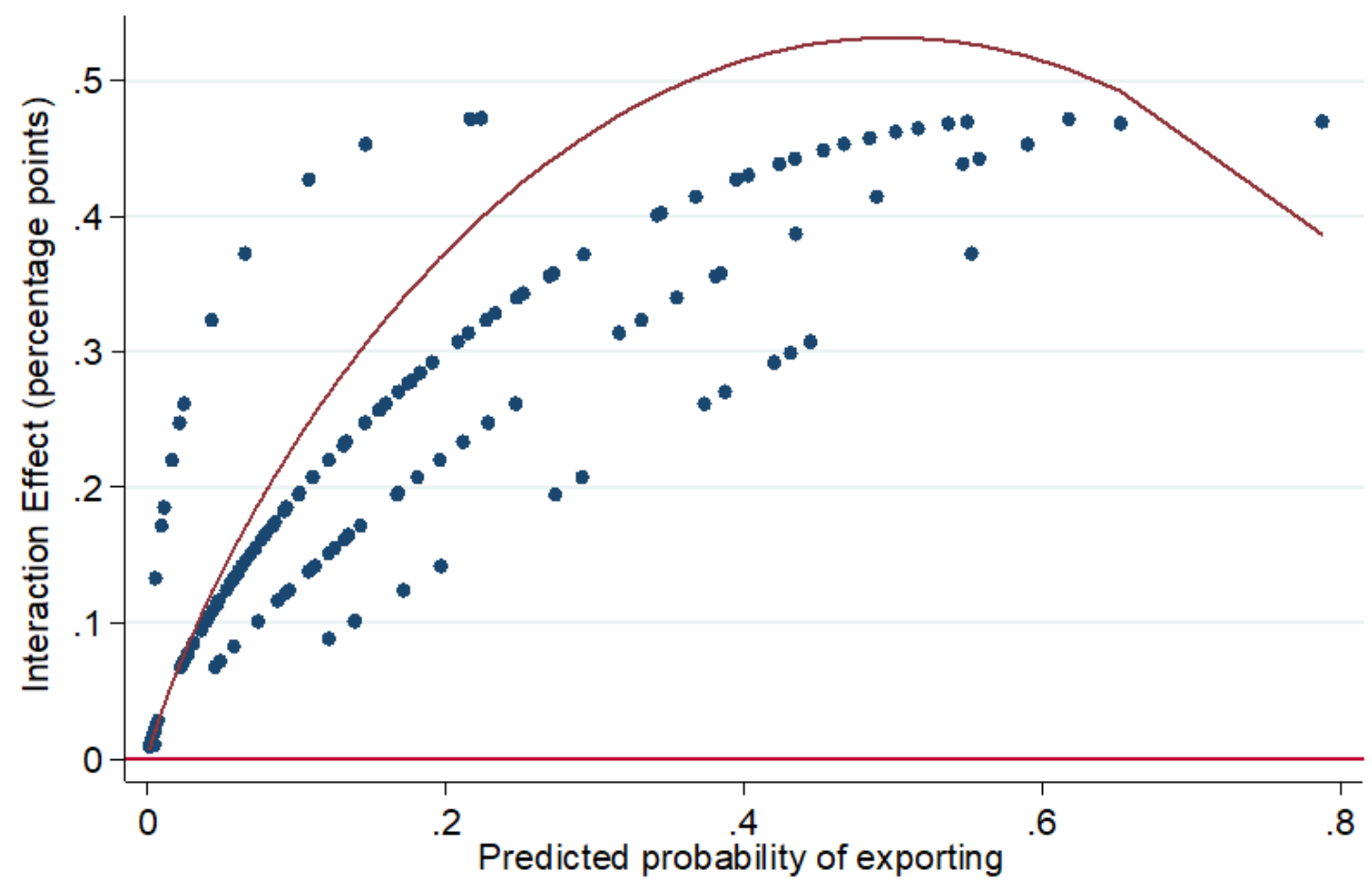

Figure 4. Statistic as a function of the predicted probability to export

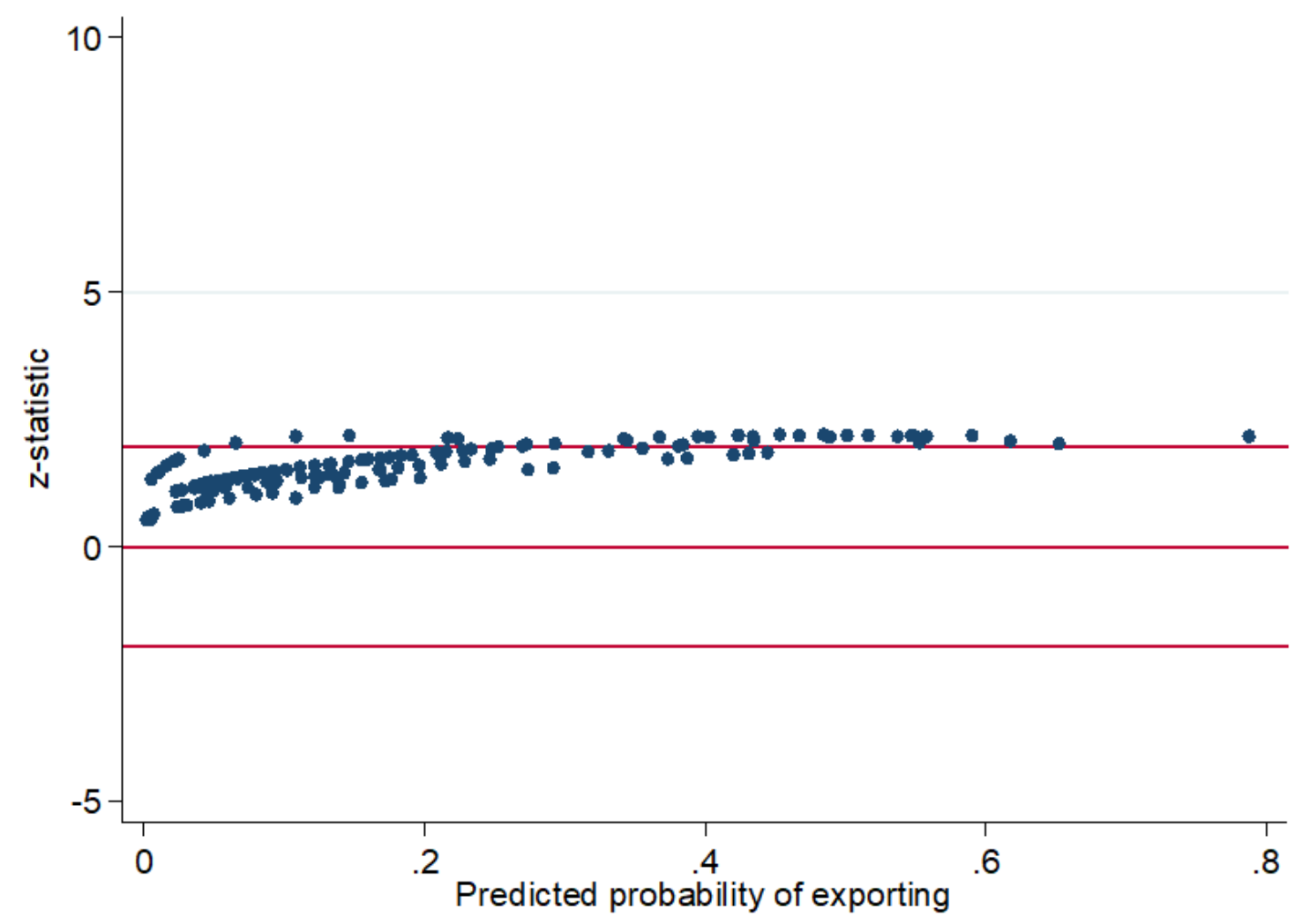


Figure 5. Distribution of business owners according to the predicted probability of exporting (full model)

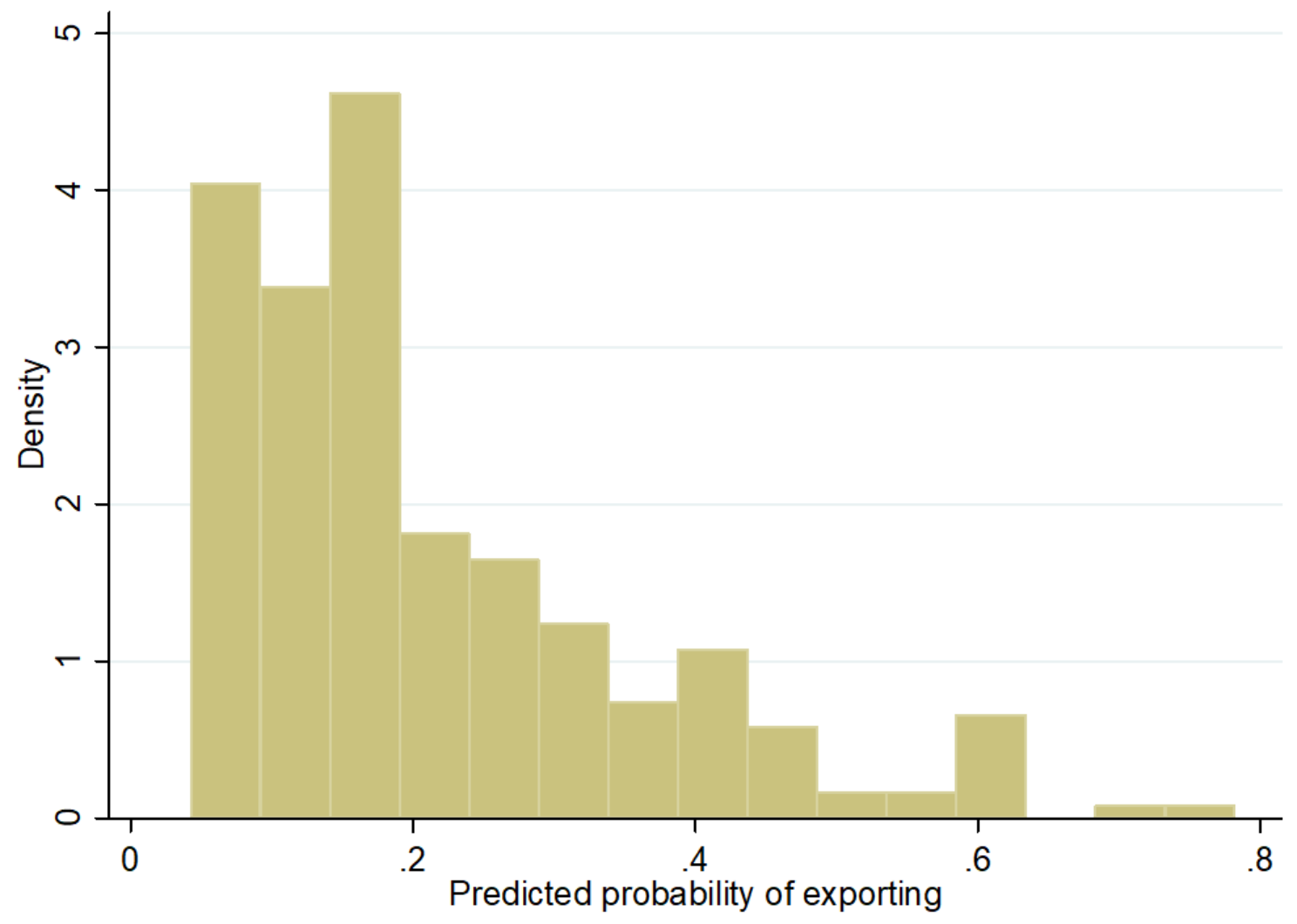




\section{List of Tables}

Table 1. Descriptive statistics for the study variable

\begin{tabular}{|l|c|c|c|c|}
\hline & Mean & Std. dev. & Minimum & Maximum \\
\hline Internationalization & & & & \\
\hline Export propensity & 0.2114 & 0.4091 & 0 & 1 \\
\hline Agility & & & & \\
\hline $\begin{array}{l}\text { Generative-based agility } \\
\text { (Past entrepreneurial experience) }\end{array}$ & 0.2561 & 0.4374 & 0 & 1 \\
\hline Process agility & 0.1138 & 0.3182 & 0 & 1 \\
\hline Entrepreneur's profile & & & & 0 \\
\hline Gender (male) & 0.6382 & 0.4815 & 27 & 1 \\
\hline Age (years) & 46.34 & 9.95 & 0 & 1 \\
\hline Primary education & 0.4268 & 0.4956 & 0 & 1 \\
\hline Secondary education & 0.0976 & 0.2973 & 0 & 1 \\
\hline Post secondary education & 0.4756 & 0.5004 & 0 & \\
\hline Business profile & & & & 54 \\
\hline Business age (years) & 13.68 & 10.97 & 1 & 125 \\
\hline Business size (employees) & 3.09 & 10.30 & 1 & 1 \\
\hline High perceived market competition & 0.6870 & 0.4647 & 0 & 1 \\
\hline Extractive sector & 0.1016 & 0.3028 & 0 & 1 \\
\hline Manufacturing sector & 0.3130 & 0.4647 & 0 & 1 \\
\hline Business services & 0.2276 & 0.4202 & 0 & 0 \\
\hline Consumer services & 0.3578 & 0.4803 & 0 & 1 \\
\hline
\end{tabular}

Sample size: 246 business owners 
Table 2. Logit regression results: Sources of agility and export propensity

\begin{tabular}{|l|l|l|}
\hline & Coefficients (Std. error) & Average marginal effect \\
\hline Past entrepreneurial experience & $0.7946(0.3959)^{* *}$ & $0.1160(0.0597)^{* *}$ \\
\hline Process agility & $1.0472(0.7018)$ & $0.1529(0.1018)$ \\
\hline $\begin{array}{l}\text { Past entrepreneurial experience } \times \\
\text { Process agility }\end{array}$ & $1.8514(0.6282)^{* * *}$ & $0.2331(0.1093)^{* *}$ \\
\hline Gender (male) & $-0.0165(0.3742)$ & $-0.0024(0.0546)$ \\
\hline Entrepreneur's age (ln years) & $-0.2770(0.9670)$ & $-0.0404(0.1414)$ \\
\hline Primary studies & $-0.8805(0.4048)^{* *}$ & $-0.1286(0.0581)^{* *}$ \\
\hline Secondary studies & $0.4192(0.5244)$ & $0.0612(0.0760)$ \\
\hline Business age (ln years) & $-0.0597(0.2420)$ & $-0.0087(0.0353)$ \\
\hline Business size (ln employees) & $0.3306(0.1856)^{*}$ & $0.0483(0.0266)^{*}$ \\
\hline Perceived competition & $-0.1090(0.3632)$ & $-0.0159(0.0530)$ \\
\hline Industry dummies & Yes & \\
\hline Intercept & $-0.3995(1.4355)$ & \\
\hline Goodness of fit statistics & & \\
\hline Log likelihood & -112.56 & \\
\hline Wald test (chi2) & $25.59^{* * *}$ & \\
\hline Pseudo R2 (Mc Fadden) & 0.1129 & \\
\hline Average VIF (min - max) & $1.43(1.04-2.47)$ & \\
\hline Observations & 246 & \\
\hline Robust sto & & \\
\hline
\end{tabular}

Robust standard errors are presented in brackets. For each independent variable (x) the average marginal effect (AME) is estimated as $A M E_{\mathbf{x}}=\frac{1}{N} \sum_{i=1}^{N}\left\{F\left(\beta \mathbf{x} \mid \mathbf{x}_{i}=1\right)-F\left(\beta \mathbf{x} \mid \mathbf{x}_{i}=0\right)\right\}$. For the interaction term, the robust marginal effect for changes in the two dummy variables $\left(x_{1}, X_{2}\right)$ is estimated by $\hat{\gamma}_{x 1, x 2}=\frac{\Delta^{2} F(X, \hat{\beta})}{\Delta x_{1} \Delta x_{2}}$, where $X=x_{1}, x_{2}$ (Ai and Norton, 2003). *, ${ }^{* *}, * * *$ indicate significance at the $10 \%, 5 \%$ and $1 \%$, respectively. 
Appendix

Table A1. Correlation matrix

\begin{tabular}{|c|c|c|c|c|c|c|c|c|c|c|c|c|c|c|c|}
\hline & & 1 & 2 & 3 & 4 & 5 & 6 & 7 & 8 & 9 & 10 & 11 & 12 & 13 & 14 \\
\hline 1 & Export propensity & 1 & & & & & & & & & & & & & \\
\hline 2 & $\begin{array}{l}\text { Past entrepreneurial } \\
\text { experience }\end{array}$ & $0.309^{* * *}$ & 1 & & & & & & & & & & & & \\
\hline 3 & Process agility & $0.084^{* * *}$ & $0.100^{* * *}$ & 1 & & & & & & & & & & & \\
\hline 4 & Gender (male) & $0.047^{* *}$ & 0.034 & $0.040^{*}$ & 1 & & & & & & & & & & \\
\hline 5 & Entrepreneur's age & 0.006 & $0.181^{* * *}$ & -0.019 & $-0.094^{* * *}$ & 1 & & & & & & & & & \\
\hline 6 & Primary education & $-0.084^{* * *}$ & 0.014 & -0.036 & $-0.072^{* * *}$ & $0.188^{* * *}$ & 1 & & & & & & & & \\
\hline 7 & Secondary education & 0.024 & -0.005 & -0.009 & 0.034 & $-0.131^{* * *}$ & $-0.310^{* * *}$ & 1 & & & & & & & \\
\hline 8 & $\begin{array}{l}\text { Post secondary } \\
\text { education }\end{array}$ & $0.069^{* * *}$ & -0.011 & $0.042^{*}$ & $0.051^{* *}$ & $-0.108^{* * *}$ & $-0.809^{* * *}$ & $-0.308^{* * *}$ & 1 & & & & & & \\
\hline 9 & Business age (years) & -0.060 & $-0.146^{* *}$ & -0.051 & 0.053 & $0.481^{* * *}$ & $0.105^{*}$ & 0.033 & $-0.123^{*}$ & 1 & & & & & \\
\hline 10 & $\begin{array}{l}\text { Business size } \\
\text { (employees) }\end{array}$ & $0.326^{* * *}$ & $0.047^{* *}$ & $0.183^{* * *}$ & $0.096^{* * *}$ & $0.052^{* *}$ & -0.033 & -0.013 & $0.041^{*}$ & $0.145^{* *}$ & 1 & & & & \\
\hline 11 & $\begin{array}{l}\text { High perceived } \\
\text { market competition }\end{array}$ & 0.004 & -0.037 & -0.062 & 0.037 & -0.030 & 0.028 & 0.080 & -0.075 & -0.056 & 0.082 & 1 & & & \\
\hline 13 & Manufacturing sector & -0.070 & 0.026 & 0.062 & $0.308^{* * *}$ & -0.085 & $0.144^{* *}$ & -0.015 & $-0.134^{* *}$ & -0.003 & $0.124^{*}$ & 0.021 & $-0.227^{* * *}$ & 1 & \\
\hline 14 & Business services & $0.123^{*}$ & $0.148^{* *}$ & $0.111^{*}$ & $-0.197^{* * *}$ & 0.017 & $-0.233^{* * *}$ & -0.048 & $0.260^{* * *}$ & $-0.119^{*}$ & -0.093 & 0.053 & $-0.183^{* * *}$ & $-0.367^{* * *}$ & 1 \\
\hline 15 & Consumer services & -0.013 & -0.069 & -0.081 & $-0.179^{* * *}$ & 0.033 & 0.025 & 0.012 & -0.032 & 0.044 & 0.002 & -0.045 & $-0.251^{* * *}$ & $-0.504^{* * *}$ & $-0.405^{\text {*** }}$ \\
\hline
\end{tabular}

$*, * *, * * *$ indicate significance at the $10 \%, 5 \%$ and $1 \%$, respectively. 
